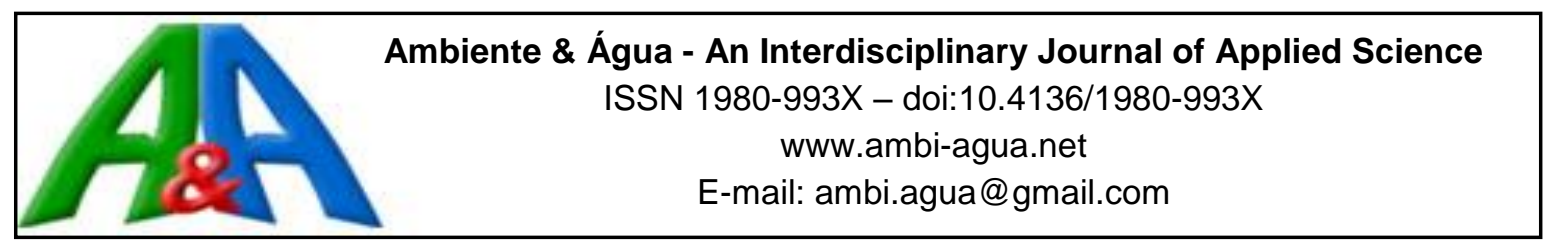

\title{
Urban influence on the water quality of the Uberaba River basin: an ecotoxicological assessment
}

\author{
ARTICLES doi:10.4136/ambi-agua.2127
}

Received: 25 Apr. 2017; Accepted: 17 Dec. 2017

\begin{abstract}
Ana Luisa Curado; Camila Cunha de Oliveira; William Raimundo Costa; Ana Carolina Borella Marfil Anhê; Ana Paula Milla dos Santos Senhuk*

Universidade Federal do Triângulo Mineiro (UFTM), Uberaba, MG, Brasil Instituto de Ciências Tecnológicas e Exatas (ICTE), Departamento de Engenharia Ambiental. E-mail: anacurado.90@gmail.com, camilacoliveiira@gmail.com,williamraimundo.costa@ hotmail.com, anacbanhe@yahoo.com.br, anapmilla@yahoo.com.br

${ }^{*}$ Corresponding author
\end{abstract}

\begin{abstract}
Ecotoxicological tests applied to Tradescantia pallida, Allium cepa and Lactuca sativa were used to assess the quality of the Uberaba River basin under urban area influence. Water samples were collected at eight different points during the dry season. The samples were assessed using the following toxicity indicators: micronuclei percentage in $T$. pallida pollen grains (TRAD-MN), seed germination, root growth, mitotic index (MI) and micronuclei in $A$. cepa root-cells, and seed germination and root growth in L. sativa. Water physicochemical parameters such as temperature, dissolved oxygen (DO), $\mathrm{pH}$ and electric conductivity were assessed in situ. The three plant species were efficient bio-indicators, since they presented good cost-benefit and fast and easily interpreted results, thus completing the physicochemical parameters. There was strong correlation between seed germination and root growth among the ecotoxicological parameters assessed in L. sativa and A. cepa. The micronuclei percentage in T. pallida and the MI in A. cepa presented strong correlation with water electric conductivity and moderate and negative correlation with DO. Water electric conductivity ranged from 75 to $438 \mu{\mathrm{S} . \mathrm{cm}^{-1}}$; and the DO concentrations ranged from 0.5 to $6.9 \mathrm{mg} . \mathrm{L}^{-1}$. The importance of pollution control measures in the Uberaba River basin stands out. From the supply-water capture point, the basin is strongly affected by pollution, mainly in the tributaries that cross the city. It presents a short, or almost absent, riparian forest line, residues on the river banks, and it is impacted by discharges of untreated sewage, among other anthropic actions.
\end{abstract}

Keywords: Water pollution, ecotoxicology, bioindicator.

\section{Influência urbana na qualidade da água da bacia do Rio Uberaba: uma avaliação ecotoxicológica}

\section{RESUMO}

Testes ecotoxicológicos com Tradescantia pallida, Allium cepa e Lactuca sativa foram utilizados para avaliar a qualidade da bacia do rio Uberaba, sob influência da área urbana. Amostras de água coletadas em oito pontos, no período seco, foram avaliadas pelos indicadores de toxicidade: porcentagem de micronúcleos em grãos de pólen de T. pallida (TRAD-MN), 
germinação das sementes, crescimento radicular, índice mitótico (MI) e micronúcleos em células da raiz de A. cepa, e germinação e crescimento radicular de L. sativa. Os parâmetros físico-químicos da água: temperatura, oxigênio dissolvido (OD), $\mathrm{pH}$ e condutividade elétrica foram analisados no momento da coleta. As três espécies vegetais foram eficientes como bioindicadores, tendo bom custo-benefício e resultados rápidos e facilmente interpretáveis, complementando os parâmetros físico-químicos. Dentre os parâmetros ecotoxicológicos analisados em L. sativa e A. cepa, foi verificada forte correlação entre a germinação das sementes e o crescimento radicular. A porcentagem de micronúcleos em T. pallida e MI em A. сера apresentaram forte correlação com condutividade elétrica da água e correlação moderada e negativa com OD. A condutividade elétrica da água variou de 75 a $438 \mu \mathrm{S} \mathrm{cm}^{-1}$ e as concentrações de OD, de 0,5 a 6,9 mg. $\mathrm{L}^{-1}$. Evidencia-se a importância de medidas de controle da poluição na bacia do rio Uberaba, que a partir do ponto de captação de água para abastecimento, encontra-se altamente impactado, principalmente os afluentes que cortam o município, apresentando estreita faixa de mata ciliar ou nenhuma, depósito de resíduos nas margens, lançamento de esgoto in natura, entre outras ações antrópicas.

Palavras-chave: Poluição da água, ecotoxicologia, bioindicador.

\section{INTRODUCTION}

Environmental sanitation is essential for the promotion of public health and environmental sustainability. It is estimated that improper sanitation causes 280 thousand diarrheal deaths yearly, and is an important risk factor for many neglected tropical diseases, mainly impacting the infant population in developing countries (WHO, 2016).

Population growth in Brazil, which is not accompanied by investment in sanitation, deals with low domestic sewage collection and treatment indices. Therefore, most of monitoring points in the surface water of urban centers are in poor quality, a fact that compromises the potable-water supply (ANA, 2017).

In this context, Uberaba County holds a privileged position in Minas Gerais State, because more than $70 \%$ of its domestic effluents are treated and solid residues are disposed of in landfills. However, the water bodies in the urban area are highly degraded and represent risk to both the population and the environment (Mateus et al., 2015).

Many physicochemical and biological parameters are used by the responsible agencies to monitor and control water pollution. These parameters are fundamental to classify and frame the water bodies according to water quality classes, and potability and bathing patterns, indicating the impacts generated by the inadequate management of water resources (ANA, 2017). However, these analyses do not allow for the detecting of the effect of water pollution on biological systems, since they concern samplings of immediate variables that do not allow the understanding these ecosystems' dynamics as a whole.

The comprehension of effects on ecosystems, resulting from the chronic exposure to a range of pollutants, is a challenge that demands innovative approaches. Water ecosystems are the main receptors of pollutant mixes deriving from domestic, industrial and agricultural effluent disposal. Many of these effluents, such as chemical substances (pharmaceutical residues, endocrine disruptors, hormones, among others) and microorganisms, including reemerging disease pathogens such as protozoa belonging to genera Cryptosporidum and Giardia, that are not removed through conventional water and sewage treatment, can be considered emerging pollutants (Gavrilescu et al., 2015).

Chemical data themselves are not enough to assess the potential risks of emerging pollutants, mainly when it comes to long-term and low-concentration exposure. In parallel, biomonitoring procedures have great potential to increase trust in risk-to-health studies and to 
better understand the functioning of services provided by water ecosystems. Among the different biosensors used in ecotoxicology, plants have genetic features that turn them into efficient mutagenic and cytotoxicity detection models because they present quantifiable results of easy access (Favaro et al., 2016; Haq et al., 2017; Merlo et al., 2011).

Thus, the aim of the present study was to assess the quality of the water in the Uberaba River basin under the influence of urban area, based on ecotoxicological bioassays and physicochemical parameters.

\section{MATERIAL AND METHODS}

\subsection{Study area}

The present study was conducted in Uberaba City, Triângulo Mineiro region - Minas Gerais State. The total area of the county corresponds to approximately $4,500 \mathrm{~km}^{2}$ and the population is estimated at approximately 325 thousand inhabitants; more than $90 \%$ of them live in the urban area. According to Köppen, the climate in the region is classified as tropical Aw, with rainfall concentration in spring and summer (from October to March); fall and winter are dry (from April to September). The mean annual rainfall is approximately $1,400 \mathrm{~mm} ; 34 \%$ of the rain events take place in December and January (Uberaba, 2012).

The Uberaba River is the main water body in the county and is responsible for most of the water supply to the population. This river belongs to Grande River basin; its spring is located next to the crossroad to Ponte Alta City (on BR-262) and flows through approximately $140 \mathrm{Km}$, until reaching the Grande River. Besides crossing Uberaba County (East/West direction), the river also passes by Veríssimo, Conceição das Alagoas, and Planura counties. The Uberaba River has a sewage treatment station (STS) able to treat $456 \mathrm{~L} . \mathrm{s}^{-1}$ of sewage, approximately $74 \%$ of the domestic effluents in Uberaba (2007) (Uberaba, 2012).

The collection points were selected throughout $12 \mathrm{Km}$ of the Uberaba River basin, starting from the upstream of supply-water capture station (A), crossing the urban area (B, and D), at three tributaries $(\mathrm{C}, \mathrm{E}$ and $\mathrm{F})$, until the upstream $(\mathrm{G})$ and the downstream $(\mathrm{H})$ of the effluent disposal treated in the STS (Figure 1).

The water sample collections and the monitoring of physicochemical parameters were performed in July 2016 during the dry season. 


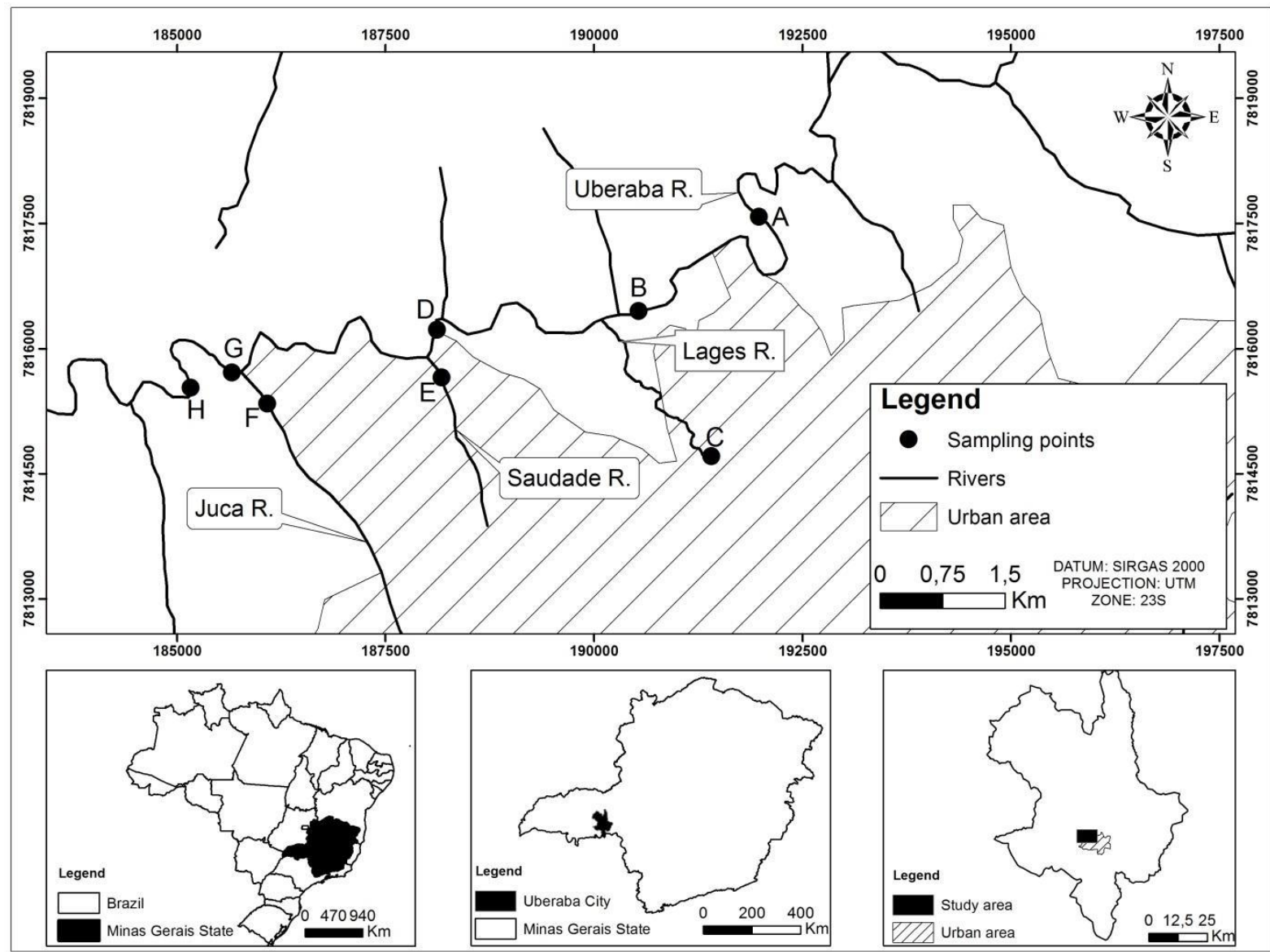

Figure 1. Sampling points at Uberaba River basin, Uberaba-MG, Brazil.

\subsection{Tradescantia pallida bioassay - TRAD-MN}

The micronuclei analysis applied to T. pallida pollen grain cells was conducted according to the methodology proposed by Ma (1981) and Mielli et al. (2009), with modifications. Between 5 to $10 \mathrm{~T}$. pallida floral stems, approximately $10 \mathrm{~cm}$ long, were kept in beakers containing distilled water for 24 hours, for adaptation purposes. Next, they were exposed to the negative control (distilled water), to the positive control ( $2 \%$ formaldehyde) and to the water collected at the sampling points, for another 6 hours. The floral stems were once more placed in distilled water, for 24 hours; subsequently, the inflorescences were fixed in Carnoy 3:1 solution (3 parts of ethanol per 1 part of acetic acid) and stored in 70\% alcohol.

The fixed flower buds were dissected and inked in carmine acetic (prepared through boiling in $0.5 \mathrm{~g}$ carmine powder in $100 \mathrm{~mL}$ of $45 \%$ acetic acid). The micronuclei counting was performed in optical microscope at 400x magnitude, in a random group comprising 300 tetrads, thus totaling five slides per point. The micronuclei frequency was expressed as a percentage.

\subsection{Allium cepa bioassay}

Bioassay using A. cepa (onion) seeds was performed according to the methodology proposed by Bianchi et al. (2011), with adaptations. Seeds belonging to variety Piriform Bay (ISLA PAK brand), with no chemical treatment, were left to germinate in petri dishes covered with filter paper, saturated in $4 \mathrm{~mL}$ of the collected water and distilled water (control) samples. Each assay was conducted in triplicate, with 15 seeds per dish. The ecotoxicological assessment was performed through germination percentage and root growth inhibition, after the samples were kept for 5 days in the dark at room temperature.

Subsequently, the roots were sectioned, transferred to $50 \mathrm{~mL}$ tubes containing Carnoy 3:1 solution and stored in a refrigerator until slide preparation. The roots were taken off the fixer 
and submitted to 3 baths in distilled water, for 5 minutes. Next, they were dried in filter paper, hydrolyzed in $\mathrm{HCl} 1 \mathrm{~N}$ at $60^{\circ} \mathrm{C}$ for 10 minutes and washed in distilled water ( 3 baths). As a next step, the roots were dried in filter paper and transferred to dark flasks with Schiff reactive for approximately 2 hours.

The roots were once more washed in distilled water for total ink-excess removal. The meristematic region of each root was sectioned, smashed in one drop of carmine acetic, and covered with coverslip. Five slides were prepared for each treatment and 500 cells were counted per slide in optical microscope under 400x magnitude, in order to assess the cytotoxic and mutagenic effects. The mitotic index (MI), which consists of the percentage of cells into division, and the micronuclei frequency were calculated.

\subsection{Lactuca sativa bioassay}

The bioassays using L. sativa (lettuce) seeds (ISLA PAK), Manteiga variety, without previous chemical treatment, were performed according to the methodology proposed by Sobrero and Ronco (2004). The seeds were disposed in petri dishes, just as in the A. cepa assay. The ecotoxicological assessment was conducted using germination percentage and root growth inhibition.

\subsection{Physicochemical parameters}

The water quality physicochemical parameters such as temperature, $\mathrm{pH}$, electrical conductivity and dissolved oxygen (DO) were analyzed in situ by using the YSI multiparameter probe.

\subsection{Data analysis}

Data of the ecotoxicological assays were subjected to ANOVA to compare the treatments and, when significance level reached $(p<0.05)$, the Tukey test was applied for multiple comparison in the BioEstat 5.0 software. The ecotoxicological results were also compared to the physicochemical parameters by calculating the Pearson's coefficient correlation.

\section{RESULTS AND DISCUSSION}

\subsection{Tradescantia pallida bioassay - TRAD-MN}

The micronuclei frequencies in T. pallida were higher than the frequencies in the negative control, in all samples, thus ranging from $2.73 \%$ to $6.13 \%$ (Figure 2). As spontaneous mutation rates do not often exceed $2 \%$ of micronuclei, frequencies higher than that correspond to the exposure to polluted environments and are considered as genotoxic effect (Pereira et al., 2013).

The samples from points $\mathrm{B}, \mathrm{C}$ and $\mathrm{F}$ exceeded the micronuclei frequency shown by the positive control (4.5\%), which were exposed to formaldehyde (an agent seen as toxic to plants) (Mielli et al., 2009). Points B and C showed evident anthropic changes such as domestic effluent discharge in the water course, besides unpleasant odor, absence of riparian forest and residue accumulation on the riverbanks, among others. Point F, which is located in the final portion of Juca Stream, had unpleasant odor and received effluent from the food industry (poultry slaughter). Although treated, this effluent is discharged in the stream and has significant pollutant load, a fact that compromises the health of the ecosystem.

The point A has presented lower micronuclei frequency in comparison to the other points; however, some anthropic changes were observed in the region, such as a short riparian forest line and the deposition of residues at some forest points. There are also many small properties around this point, that often have conventional cesspools and breed animals near the river. 


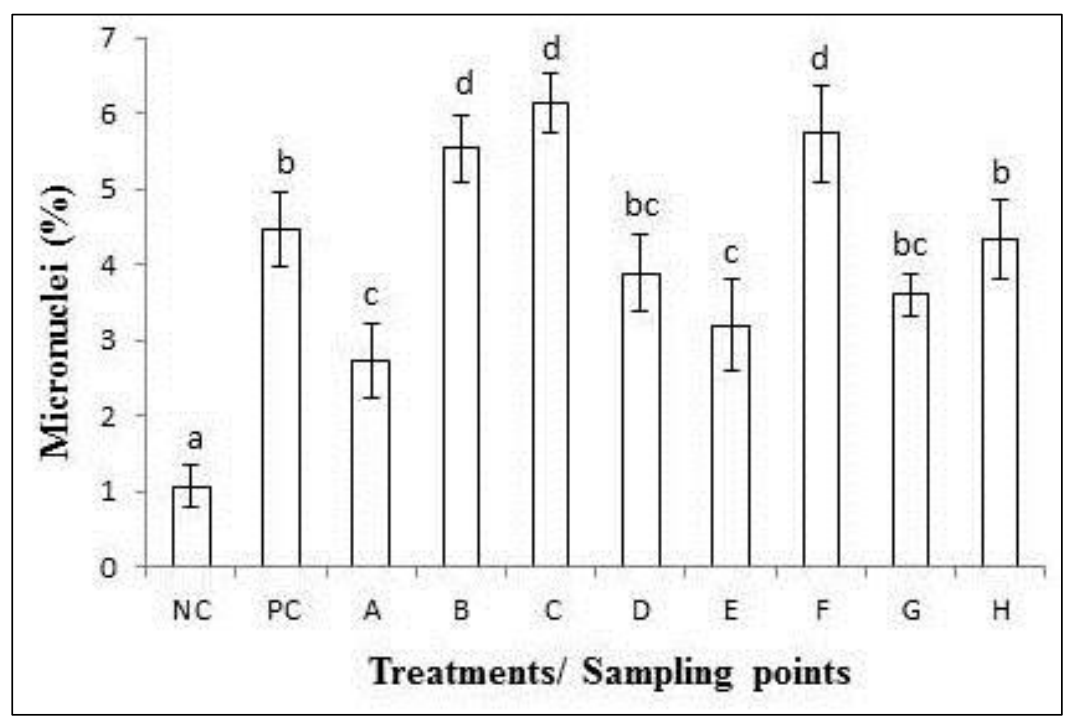

Figure 2. $\mathrm{NC}=$ negative control. $\mathrm{PC}=$ positive control. Bars represent the standard deviation of the mean. Different letters indicate significant difference by ANOVA and Tukey $(p<0,05)$. Frequency of micronuclei in T. pallida exposed to different water samples from the Uberaba River basin, Uberaba-MG, Brazil.

The ecotoxicological assays using T. pallida are quite common due to the easiness of visualizing the micronuclei and because they are of fast conduction and low cost. This plant is considered a bio-indicator of high sensitivity to genotoxic agent exposure, besides its large availability and seedling collection (Klumpp et. al., 2006; Mišík et al., 2011).

Costa et al. (2014) also reported the genotoxic effect of water bodies on T. pallida. They assessed the quality of the water from the Schmidt Stream and from the Sinos River in Campo Bom (Rio Grande do Sul State) and found micronuclei frequencies between 3.2\% and 4.81\%. The results have pointed out the peculiar conditions of each assessed environment; therefore, they have become significant indicators able to integrate water quality management and control programs.

Another study involving T. pallida was conducted by Umbuzeiro et al. (2007) in Cristais River, at metropolitan region of São Paulo city. The authors found $1.8 \%$ of micronuclei in plants exposed to water from the tributary considered a reference point; and $6.2 \%$ of micronuclei in the downstream of a textile industry. These values are similar to those in the present study concerning points $\mathrm{B}, \mathrm{C}$ and $\mathrm{F}$.

\subsection{Allium cepa bioassay}

The germination rate of $A$. cepa seeds was high in all points $(83.2 \%$, on average), except for Point $C(37.8 \%)$ (Table 1). The seeds exposed to water samples from this point, although presenting high MI, suffered mutation throughout the mitotic division, a fact that led to the higher micronuclei rate and higher root growth inhibition in comparison to the other points.

These parameters have been broadly used to detect the lethal and sub-lethal effect of lotic ecosystem toxicity on A. cepa seeds and plantlets (Braga and Lopes, 2015).

On the other hand, some points, such as A and B, presented seed germination and root growth similar to the control, but with high micronuclei rates. Cytotoxicity is not always inversely correlated with genotoxicity in A. серa. The water pollution by domestic effluent and by the deposition of residues on the riverbanks found in these points has probably increased the concentration of nutrients in the water to the extent to favor seed germination and root growth, despite causing chromosome mutations (Echeverry and Pinilla, 2007). 
Table 1. Ecotoxicological effects on A. cepa exposed to different water samples from the Uberaba River basin, Uberaba-MG, Brazil.

\begin{tabular}{ccccc}
\hline Treatment/ sampling points & Germination $(\%)$ & Root $(\mathbf{c m})$ & MI $(\%)$ & MN $(\%)$ \\
\hline Control & $80.0 \pm 6.7^{\mathrm{a}}$ & $2.9 \pm 0.5^{\mathrm{a}}$ & $8.1 \pm 0.6^{\mathrm{a}}$ & $0.2^{\mathrm{a}} \pm 0.1^{\mathrm{a}}$ \\
A & $71.1 \pm 7.7^{\mathrm{a}}$ & $2.3 \pm 0.3^{\mathrm{ab}}$ & $5.6 \pm 0.3^{\mathrm{b}}$ & $0.8^{\mathrm{b}} \pm 0.2^{\mathrm{b}}$ \\
B & $82.2 \pm 3.8^{\mathrm{a}}$ & $2.8 \pm 0.1^{\mathrm{a}}$ & $9.8 \pm 0.7^{\mathrm{c}}$ & $0.9 \pm 0.1^{\mathrm{b}}$ \\
C & $37.8 \pm 15.4^{\mathrm{b}}$ & $1.5 \pm 0.1^{\mathrm{b}}$ & $8.9 \pm 0.7^{\mathrm{ac}}$ & $0.9 \pm 0.2^{\mathrm{b}}$ \\
D & $82.2 \pm 3.8^{\mathrm{a}}$ & $2.2 \pm 0.3^{\mathrm{ab}}$ & $8.2 \pm 0.6^{\mathrm{a}}$ & $0.4^{\mathrm{a}} \pm 0.2^{\mathrm{a}}$ \\
E & $93.3^{\mathrm{a}}$ & $2.2 \pm 0.2^{\mathrm{ab}}$ & $5.0 \pm 0.3^{\mathrm{b}}$ & $0.7 \pm 0.2^{\mathrm{b}}$ \\
F & $82.2 \pm 7.7^{\mathrm{a}}$ & $2.2 \pm 0.3^{\mathrm{ab}}$ & $6.8 \pm 0.6^{\mathrm{d}}$ & $0.5 \pm 0.1^{\mathrm{a}}$ \\
G & $88.9 \pm 3.8^{\mathrm{a}}$ & $2.2^{\mathrm{ab}}$ & $8.7 \pm 0.5^{\mathrm{ac}}$ & $0.6 \pm 0.2^{\mathrm{ab}}$ \\
H & $82.2 \pm 13.9^{\mathrm{a}}$ & $2.4 \pm 0.4^{\mathrm{a}}$ & $7.7 \pm 0.4^{\mathrm{ad}}$ & $0.4 \pm 0.1^{\mathrm{a}}$ \\
\hline
\end{tabular}

$\mathrm{MI}=$ Mitotic index; $\mathrm{MN}=$ Micronuclei frequency. Different letters indicate significant difference by ANOVA and Tukey $(p<0,05)$.

These results were similar to those found by Mendes et al. (2011) in samples from Marombas River (Santa Catarina State). According to them, despite the agrochemicals detected in the water, the results suggest that root growth was not sensitive to pollutants under the assay conditions.

Düsman et al. (2011) found cytotoxicity in the water of urban streams in Maringá (Paraná State) to the meristematic cells of A. cepa roots. They attributed the increased MI to the possible presence of mitogenic-capacity substances causing uncontrolled cell proliferation and, even, tumor tissue formation.

\subsection{Lactuca sativa bioassay}

Just as in A. cepa, the germination of L. sativa seeds was high in all points and similar to the control (96.5\%, on average), except for Point C (73.3\%) (Table 2). The water samples from this point also caused root growth inhibition. The germination of L. sativa seeds and the root growth may be highly affected by the exposure to different domestic and industrial sewage doses.

The other points, except for Point A, presented root growth increase in comparison to the control. Echeverry and Pinilla (2007) observed similar L. sativa root-growth results in water samples from the Bogotá River (Colombia), and related such result to the high concentration of nutrients from domestic discharges.

Table 2. Ecotoxicological effects on $L$. sativa exposed to different water samples from the Uberaba River basin, Uberaba-MG, Brazil.

\begin{tabular}{ccc}
\hline Treatment/ Sampling points & Germination $(\%)$ & Root $(\mathbf{c m})$ \\
\hline Control & $97.8 \pm 3.8^{\mathrm{a}}$ & $6.9 \pm 0.2^{\mathrm{a}}$ \\
A & $95.6 \pm 3.8^{\mathrm{a}}$ & $6.9 \pm 0.5^{\mathrm{ab}}$ \\
B & $100.0^{\mathrm{a}}$ & $7.8 \pm 0.3^{\mathrm{b}}$ \\
C & $73.3 \pm 6.7^{\mathrm{b}}$ & $3.9 \pm 0.4^{\mathrm{c}}$ \\
D & $91.1 \pm 7.7^{\mathrm{a}}$ & $7.7 \pm 0.7^{\mathrm{b}}$ \\
E & $97.8 \pm 3.8^{\mathrm{a}}$ & $7.3 \pm 0.4^{\mathrm{ab}}$ \\
F & $93.3^{\mathrm{a}}$ & $7.9 \pm 0.1^{\mathrm{b}}$ \\
G & $100.00^{\mathrm{a}}$ & $7.5 \pm 0.1^{\mathrm{b}}$ \\
H & $97.8 \pm 3.8^{\mathrm{a}}$ & $7.3 \pm 0.1^{\mathrm{b}}$ \\
\hline
\end{tabular}

Different letters indicate significant difference by ANOVA and Tukey $(p<0,05)$. 


\subsection{Physicochemical parameters}

The Uberaba River is classified as Class 2 according to the CONAMA Resolution $\mathrm{n}^{\circ}$. 357/2005, and its effluents, as they have no classification, belong to the same class (CONAMA, 2005). However, the chance of having Uberaba River meeting the water quality limits set by Class 2 is almost nil, since it is affected by different anthropic actions and by the confluence with polluted effluents, mainly the Lages Stream, which is channeled and drains most of Uberaba's urban area (Mateus et al., 2015).

The analysis of physicochemical parameters showed that all points were in compliance with the $\mathrm{pH}$ set by the quality classes described in the legislation (between 6 and 9) (CONAMA, 2005) (Table 3). Point A presented the lowest temperature $\left(21.3^{\circ} \mathrm{C}\right)$ and the lowest water electric conductivity $\left(75.2 \mu \mathrm{S} . \mathrm{cm}^{-1}\right)$. This point also showed the highest DO concentration (6.9 mg. $\left.\mathrm{L}^{-1}\right)$, and was the only one in conformity with the standard set by the legislation for Class 2.

The highest temperatures were recorded in Points $\mathrm{C}$ and $\mathrm{H}$. Point $\mathrm{C}$ also stood out for presenting the highest water conductivity $\left(586 \mu{\mathrm{S} . \mathrm{cm}^{-1}}^{-1}\right)$ and the lowest DO $\left(0.5 \mathrm{mg} . \mathrm{L}^{-1}\right)$ concentration. An important feature of the domestic effluents lies in the fact that they have slightly higher temperature than the supply water, thus affecting processes vital to the water ecosystem (Von Sperling, 2005).

Values above $100 \mu \mathrm{S} . \mathrm{cm}^{-1}$ for water electric conductivity indicate environmental distress (CETESB, 2009). Point $F$ presented the second highest water conductivity value $\left(438.1 \mu \mathrm{S} . \mathrm{cm}^{-1}\right)$, a fact that can be explained by industrial effluent discharge into the upstream of the sampling point, thus corroborating the high micronuclei value found in T. pallida.

The Pearson's coefficient showed strong correlation between water electric conductivity and the presence of micronuclei in T. pallida $(\mathrm{r}=0.9)$, as well as moderate correlation with the mitotic index in A. cepa $(\mathrm{r}=0.7)$.

Table 3. Water physicochemical parameters in the Uberaba River basin.

\begin{tabular}{|c|c|c|c|c|}
\hline Sampling points & $\mathbf{p H}$ & Temperature $\left({ }^{\circ} \mathrm{C}\right)$ & Electrical conductivity $\left(\mu \mathrm{S} . \mathrm{cm}^{-1}\right)$ & DO $\left(\mathrm{mg} \mathrm{L}^{-1}\right)$ \\
\hline A & 7.7 & 21.3 & 75.2 & 6.9 \\
\hline $\mathrm{B}$ & 7.5 & 23.6 & 369.8 & 2.0 \\
\hline $\mathrm{C}$ & 7.7 & 25.5 & 586.0 & 0.5 \\
\hline $\mathrm{D}$ & 7.5 & 24.1 & 279.5 & 1.5 \\
\hline $\mathrm{E}$ & 7.5 & 23.3 & 128.6 & 4.5 \\
\hline $\mathrm{F}$ & 8.1 & 24.2 & 438.1 & 4.8 \\
\hline G & 8.0 & 24.0 & 416.1 & 4.5 \\
\hline $\mathrm{H}$ & 7.8 & 25.6 & 290.7 & 3.8 \\
\hline
\end{tabular}

\section{CONCLUSIONS}

The present results have evidenced that the herein-used plant species are efficient bioindicators of good cost-benefit, easy result-interpretation and of fast response to adverse environmental conditions. However, the conducted ecotoxicological tests have different sensitivities to water pollution and, whenever possible, they must be performed in combination in order to complete the physicochemical parameters. The T. pallida bioassay detected genotoxic effect caused by water samples polluted with domestic (Point $C$ ) and industrial (Point F) effluent disposal. On the other hand, the A. cepa and L. sativa seed were more sensitive to pollution resulting from domestic effluent (Point $C$ ).

From the supply-water capture point, the Uberaba River is quite affected due to its proximity to the urban area; it presents a short, or absent, riparian forest line, as well as residue 
accumulation on the riverbanks, among other anthropic actions. The river receives domestic and industrial effluents, mainly after the confluence with the Lages and Juca Streams.

The present results have evidenced the need of investigating in depth the chemical composition of the water in the Uberaba River basin and the pollution sources. It is also necessary to invest in the environmental recovery of the Uberaba River tributaries and in pollution control measures. Examples of these are the expansion of effluent collection and treatment, as well as the inspection of irregular discharge sources, in order to assure the integrity of aquatic ecosystems and the use of this natural resource by future generations.

\section{REFERENCES}

AGÊNCIA NACIONAL DE ÁGUAS - ANA (Brasil). Panorama da qualidade das águas superficiais do Brasil. Brasília, 2017. 177 p.

BIANCHI, J.; ESPINDOLA, E. L. G.; MARIN-MORALES, M. A. Genotoxicity and mutagenicity of water samples from the Monjolinho River (Brazil) after receiving untreated effluent. Ecotoxicology and Environmental Safety, v. 74, n. 4, p. 826-33, 2011.

BRAGA, J. R. M.; LOPES D. M. Citotoxicidade e genotoxicidade da água do rio Subaé (Humildes, Bahia, Brasil) usando Allium cepa L. como bioindicador. Revista Ambiente \& Água, v. 10, n. 1, p. 130-140, 2015.

COMPANHIA AMBIENTAL DO ESTADO DE SÃO PAULO - CETESB. Qualidade das águas interiores no Estado de São Paulo. Série Relatórios. São Paulo, 2009. Available at: http://cetesb.sp.gov.br/aguas-interiores/wp-content/uploads/sites/32/2013/11/variaveis.pdf. Access: February 21, 2017.

CONSELHO NACIONAL DO MEIO AMBIENTE - CONAMA (Brasil). Resolução n ${ }^{\circ} 357$, de 17 de março de 2005. Diário Oficial [da] União, n. 053, 18 mar. 2005, p. 58-63.

COSTA, G. M.; CASSANEGO, M. B. B.; PETRY, C. T.; BENVENUTI, T.; RUBIO, M. A. K.; RODRIGUES, M. A. S. Monitoramento químico e do potencial genotóxico para o diagnóstico da qualidade de corpos hídricos. Revista Brasileira de Ciências Ambientais, v. 34, p. 65-74, 2014.

DÜSMAN, E.; FARIA, J. S.; TOLEDO, F.; MAZETI, C. M.; GONÇALVES, M. E. K.; VICENTINI, V. E. P. Vegetal test-system investigation on cytotoxicity of water from urban streams located in the northeastern region of Maringá, Paraná State, Brazil. Acta Scientiarum Biological Sciences, v. 33, n. 1, p. 71-77, 2011.

ECHEVERRY, P. B.; PINILLA, C. C. Evaluación de Lactuca sativa y Selenastrum capricornutum como indicadores de toxicidad em águas. Universitas Scientiarum, v. 12, n. 2, p. 83-98, 2007.

FAVARO, A.; GRANADOS, D. T.; UTSUMI, A. G.; ANHÊ, A. C. B. M.; SENHUK, A. P. M. S. Biomonitoring of surface water toxicity related to urban and industrial wastewater release. Revista Brasileira de Ciências Ambientais, n. 42, p. 104-112, 2016.

GAVRILESCU, M.; EMNEROVÁ, K.; AAMAND, J.; AGATHOS, S.; FAVA, F. Emerging pollutants in the environment: present and future challenges in biomonitoring, ecological risks and bioremediation. New Biotechnology, v. 32, n. 1, p. 147-156, 2015.

HAQ, I.; KUMAR, S.; RAJ, A.; LOHANI, M.; SATYANARAYANA, G. N. V. Genotoxicity assessment of pulp and paper mill effluent before and after bacterial degradation using Allium cepa test. Chemosphere, v. 169, p. 642-650, 2017. 
KLUMPP, A.; ANSEL, W.; KLUMPP, G.; CALATAYUD, V.; GARRE, J. P.; HE, S. et al. Tradescantia micronucleus test indicates genotoxic potential of traffic emissions in European cities. Environmental Pollution, v. 139, p. 515-522, 2006.

MA, T. H. Tradescantia micronucleus bioassay and pollen tube chromatic aberration test for in situ monitoring and mutagens screening. Environmental Health Perspectives, v. 37, p. 85-90, 1981.

MATEUS, M. V.; GONÇALVES, J. C. S. I.; LOPES JÚNIOR, G. B.; OKURA, M. H. Análise de incerteza e modelagem de qualidade da água do Rio Uberaba, Minas Gerais. Revista Brasileira de Ciências Ambientais, n. 37, 2015.

MENDES, B. G.; BUDZIAK, D.; STOLBERG, J.; PEIXER, Z. I.; DALMARCO, J. B.; SIMIONATTO, E. L. et al. Estudo da qualidade das águas do rio Marombas (SC/Brasil), utilizando parâmetros físico-químicos e bioensaios. Revista de Ciências Ambientais, v. 5, n. 2, p. 43-58, 2011.

MERlo, C.; ABRIL, A.; AMÉ, M. V.; ARGÜEllO, G. A.; CARRERAS, H. A.; CHIAPPERO, M. S. et al. Integral assessment of pollution in the Suquía River (Córdoba, Argentina) as a contribution to lotic ecosystem restoration programs. Science of the Total Environment, v. 409, n. 23, p.5034-5046, 2011.

MIELLI, A. C.; SALDIVA, P. H. N.; UMBUZEIRO, G. A. Comparação entre as respostas do Clone 4430 e Tradescantia pallida no Teste de Micronúcleos (Trad-MN). Journal of Brazilian Society of Ecotoxicology, v. 4, n. 1-3, 49-54, 2009.

MIŠÍK, M.; MA, T. H.; NERSESYAN, A.; MONARCA, S.; KIM, J. K.; KNASMUELLER, S. Micronucleus assays with Tradescantia pollen tetrads: an update. Mutagenesis, v. 26, n. 1, p. 215-221, 2011.

PEREIRA, B. B.; CAMPOS JÚNIOR, E. O.; MORELLI, S. In situ biomonitoring of the genotoxic effects of vehicular pollution in Uberlândia, Brazil, using a Tradescantia micronucleus assay. Ecotoxicology and Environmental Safety, v. 87, p. 17-22, 2013.

SOBRERO, M. C.; RONCO, A. Ensayo de toxicidad aguda con semillas de lechuga (Lactuca sativa L). In: CASTILLO, G. (Ed.). Ensayos toxicológicos y métodos de evaluación de calidad de águas: estandarización, intercalibración, resultados y aplicaciones. Jiutepec: IMTA, 2004. p. 71-79.

UBERABA. Prefeitura Municipal. Plano de manejo emergencial: área de proteção ambiental municipal do Rio Uberaba. Uberaba, 2012.

UMBUZEIRO, G. A.; COIMBRÃO, C. A.; KUMMROW, F.; LOBO, D. J. A.; SALDIVA, P. H. N. Mutagenic activity assessment of Cristais River, São Paulo, Brazil, using the blue rayon Salmonella microsome and the Tradescantia pallida micronuclei assays. Journal of the Brazilian Society of Ecotoxicology, v. 2, p. 163-171, 2007.

VON SPERLING, M. Princípios do tratamento biológico de águas residuárias: introdução à qualidade das águas e ao tratamento de esgotos. 3. ed. Viçosa: ABES, 2005. 452 p.

WORLD HEALTH ORGANIZATION - WHO. Sanitation. Genebra, 2016. Available at: http://www.who.int/mediacentre/factsheets/fs392/en/. Accessed on: February 21, 2017. 